\title{
Perkawinan Semu dalam Perspektif Pidana Keimigrasian
}

\author{
Arya Mulia*, I Wayan Prasetya Lencana, Janitra Seskoaria \\ Program Studi Hukum Keimigrasian, Politeknik Imigrasi \\ *Correspondence e-mail: whalemulia@gmail.com
}

\begin{abstract}
Abstrak. Indonesia menjadi salah satu Negara destinasi orang asing karena banyak faktor yang membuat orang asing berdatangan, tidak sedikit orang asing yang hendak memperoleh kewarganegaraan Indonesia. Banyak cara yang dapat dilakukan oleh orang asing dalam memperoleh kewarganegaraan Indonesia, salah satunya dengan melakukan perkawinan semu. Dalam penegakan hukum keimigrasian terhadap perkawinan semu, imigrasi memiliki peranan penting terkait pembuktian tindak pidana tersebut dengan memakai UU No 6 Tahun 2011 sebagai acuannya, tindak pidana perkawinan semu sampai saat ini sulit untuk membuktikan unsur-unsur pidana nya, tetapi sebelum hal itu terjadi Imigrasi dapat mencegah dengan lebih berhati hati dalam menerbitkan dokumen keimigrasian.
\end{abstract}

Kata kunci: Keimigrasian; Perkawinan Semu; Tindak Pidana.

Abstract. Indonesia has become one of the destination countries for foreigners because of many factors that make foreigners come, many foreigners want to obtain Indonesian citizenship. There are many ways that foreigners can do in obtaining Indonesian citizenship, one of which is by conducting pseudo-marriages. In the enforcement of immigration law against pseudomarriage, immigration has an important role related to proving the crime by using Law No. 6 of 2011 as a reference, the crime of pseudo-marriage until now is difficult to prove the criminal elements, but before that happens Immigration can prevent by being more careful in issuing immigration documents.

Keywords: Crime; Immigration; Pseude-Marriage

\section{PENDAHULUAN}

Semakin mudahnya moda transportasi yang dapat digunakan manusia untuk berpindah tempat, membuat lalu lintas migrasi di dunia meningkat dari waktu ke waktu. Berpindah nya manusia dari satu tempat ke tempat yang lain tentu memberikan dampak baik pada tempat yang ditinggalkan maupun tempat yang didatangi. Migrasi atau perpindahan antarnegara sudah menjadi hal yang umum dilakukan di dunia. Indonesia menjadi salah satu destinasi atau Negara tujuan orang asing untuk datang dengan berbagai motif. Dari waktu ke waktu, lalu orang asing dari dan keluar Indonesia semakin meningkat.

Meningkatnya lalu lalang orang asing dari dan keluar wilayah RI menimbulkan dampak pada keamanan dan ketertiban Negara. Imigrasi sebagai stakeholder utama dalam urusan keluar masuknya orang asing di wilayah Indonesia mengemban tanggung jawab yang besar dalam menjaga tegaknya kedaulatan Negara. Dilihat dari fungsinya, Imigrasi turut berperan penting dalam menjaga kemanan, ketertiban, serta kedaulatan Negara Indonesia.

Dalam perilaku migrasi orang asing ke Indonesia, tidak sepenuhnya mengandung niat atau maksud yang positif. Tidak sedikit WNA yang datang ke Indonesia memiliki niat yang tidak baik atau dapat menganggu keamanan dan ketertiban di wilayah Indonesia. Indonesia menjadi salah satu Negara destinasi orang asing karena banyak faktor yang membuat orang asing berdatangan, seperti; rendahnya biaya hidup, minimnya tindak kejahatan, banyaknya sumber daya alam, dll.
Karena faktor-faktor inilah, tidak sedikit orang asing yang hendak memperoleh kewarganegaraan Indonesia.

Banyak cara yang dapat dilakukan oleh orang asing dalam memperoleh kewarganegaraan Indonesia. Cara-cara mendapatkan kewarganegaraan Indonesia ini diatur dalam Undang-Undang tentang kewarganegaraan. Perkawinan campuran merupakan beberapa cara orang asing untuk mendapatkan kewarganegaraan Indonesia

Perkawinan campuran bukan merupakan tindakan yang illegal menurut undang-undang. Namun pada implementasinya, tidak sedikit orang asing yang melakukan perkawinan campuran dengan maksud tertentu. Dengan melakukan perkawinan campuran, maka orang asing yang kawin dengan WNI akan memiliki hak untuk mendapatkan kewarganegaraan Indonesia atau sebaliknya, WNI akan kehilangan kewarganegaraan Indonesianya. Cara ini banyak dimanfaatkan orang asing untuk memperoleh kewarganegaraan Indonesia dengan relatif mudah. Bila pernikahan yang dilakukan, benar didasari oleh rasa cinta antara keduanya atau hal-hal lain yang dapat membenarkan pernikahan tersebut maka perkawinan campuran tersebut dapat dibenarkan keabsahannya. Namun jika perkawinan campuran dilakukan dengan tujuan hanya untuk mendapatkan dokumen keimigrasian atau status kewarganegaraan, maka hal ini merupakan tindak pidana keimigrasian.

\section{METODE}

Penelitian ini menggunakan metode hukum. Dari perspektif penerapan penelitian murni (atau disebut juga 
penelitian dasar atau penelitian dasar), penelitian murni biasanya berarti bermanfaat bagi pengembangan ilmu itu sendiri atau teori dan pengembangan metode penelitian. Metode pengumpulan data yang digunakan dan digunakan adalah penelitian kepustakaan, yaitu teknologi pengumpulan data melalui penelitian yang berhubungan dengan dokumen atau bahan tertulis. Data tersebut adalah data hukum tingkat primer yaitu bahan hukum yang mengikat, yang terdiri dari peraturanperaturan hukum yang berkaitan dengan objek penelitian. Dalam penelitian ini, bahan hukum primer yang digunakan adalah UU No. 6 tentang Keimigrasian Tahun 2011 serta data hukum tingkat kedua yaitu semua publikasi tentang undang-undang, yang merupakan dokumen tidak resmi, termasuk buku, kamus hukum, jurnal hukum dan karya ilmiah lainnya.

Analisis data yang digunakan adalah analisis hukum normatif, karena objek penelitian ini adalah peraturan perundang-undangan yang bersifat tetap dan mengikat. Analisis peraturan hanya dilakukan terhadap klausa yang isinya aturan (undang-undang). Setelah analisis selesai, berdasarkan pemahaman dasar tentang sistem hukum, ketentuan tertentu disusun ke dalam kategori. Teknologi yang digunakan dalam analisis data jurnal ini adalah studi studi kepustakaan, dimana analisisnya menggunakan alat bantu berupa deskripsi dan pemahaman, dan keberlakuan pasal dalam undangundang digunakan sebagai pembanding.

\section{HASIL DAN PEMBAHASAN \\ Tindak Pidana Keimigrasian}

Dalam Undang-Undang Keimigrasian, disebutkan salah satu fungsi keimigrasian adalah fungsi penegakan hukum, Imigrasi merupakan instansi yang diberikan wewenang untuk menindak segala betuk pelanggaran keimigrasian yang dilakukan, baik oleh Warga Negara Indonesia (WNI) maupun Warga Negara Asing (WNA). Terdapat dua jenis penegakan hukum yang berlaku dalam Hukum Keimigrasian yaitu tindakan administratif dan/atau Tindak Pidana Keimigrasian(Aji and Kurniawan 2018)

Hukum Keimigrasian sendiri merupakan hukum khusus di Indonesia sehingga sumber hukum formil dan materiilnya berbeda dengan hukum umum. Dengan begitu, tindak pidana Keimigrasian merupakan tindak pidana khusus yang dalam proses penindakannya mengacu pada aspek-aspek keimigrasian tertentu sehingga. Pidana keimigrasian sendiri diatur dalam Undang-Undang Keimigrasian.

\section{Perkawinan Semu \\ Keabsahan Perkawinan Semu}

Perkawinan semu adalah perkawinan antara dua orang yang tunduk pada hukum yang berbeda karena salah satu pihak adalah warga negara asing dan pihak lainnya adalah warga negara Indonesia dari agama yang sama. Dapat dilihat bahwa pengertian perkawinan antar ras yang diatur dalam UU Perkawinan No. 1 Tahun 1974 termasuk dalam pengertian perkawinan antar ras internasional. Sebelum melakukan nikah palsu, pihak yang berkewarganegaraan asing wajib mengisi surat keterangan dari negara asal yang menyatakan bahwa yang bersangkutan dapat melakukan nikah palsu dengan warga negara Indonesia.

Untuk mendapatkan dokumen-dokumen yang diperlukan, para pihak dapat menghubungi kedutaan negara asal mereka di Indonesia. Jika mereka menikah, mereka harus melapor ke penegak hukum setempat dalam waktu 60 hari sejak tanggal pernikahan. Penegakan pada perkawinan selain non-Islam terdapat pada kantor catatan sipil, sedangkan perkawinan semu yang dilakukan di luar negeri harus didaftarkan pada instansi terkait yang berwenang di negara tempat perkawinan semu itu berada, kemudian harus dilaporkan kepada perwakilan Republik Indonesia (KBRI). Perkawinan semu harus dicatatkan di luar negeri pada catatan sipil setempat dalam waktu 30 (tiga puluh) hari setelah orang tersebut kembali ke Indonesia.(Erna Ratnatningsih 2018)

\section{Penyimpangan Dalam Perkawinan Semu}

Pada dasarnya perkawinan semu adalah perkawinan campuran yang didasarkan pada tujuan tertentu. UU No 1 tentang Perkawinan tahun 1974 menjelaskan bahwa perkawinan campuran adalah perkawinan yang sah antara warga negara Indonesia (WNI) dengan warga negara asing (WNA). Perkawinan beda suku di Indonesia dilakukan dengan berbagai motif, dasar perkawinan yang diatur oleh undang-undang itu sendiri adalah hubungan lahir dan batin antara suami dan istri, dan bertujuan untuk membentuk keluarga atas dasar ketuhanan yang tunggal. Inilah sebenarnya tujuan ideal perkawinan, UU Perkawinan juga mengatur bahwa perkawinan yang efektif menganut asas tidak mudah untuk bercerai (Wirawan 2008).

Dalam proses pelaksanaannya banyak terjadi penyimpangan dalam tujuan perkawinan, khususnya perkawinan antara warga negara Indonesia dengan orang asing. Banyak pernikahan beda ras memiliki tujuan tertentu yang tidak sesuai dengan tujuan dan/atau sifat dari pernikahan itu sendiri. Dari segi keimigrasian, perkawinan beda ras untuk memperoleh kemudahan pembuatan dokumen keimigrasian Republik Indonesia dan/atau memperoleh kewarganegaraan Republik Indonesia merupakan tindak pidana dan sering disebut dengan perkawinan semu.

Perkawinan semu sendiri tergolong perkawinan yang menyimpang dan merupakan tindak pidana keimigrasian, karena perilaku tersebut telah menyebabkan meningkatnya manipulasi perkawinan antar ras di Indonesia. Dengan adanya pernikahan semu, orang asing dapat mengajukan dokumen keimigrasian dengan lebih mudah dan sederhana. Dalam banyak kasus, biasanya berupa dokumen menjadi syarat permohonan merupakan dokumen palsu seperti; KTP 
dan Dokumen Perkawinan (Kartu Nikah) (Syahrin 2017).

Perkawinan semu juga seringkali memperoleh kewarganegaraan Indonesia dengan cara yang murah dan mudah, karena dengan melaksanakan perkawinan beda ras, orang asing dapat memperoleh kewarganegaraan Indonesia tanpa melalui prosedur naturalisasi yang biasa. Menurut UU No. 12 Tahun 2006, WNA yang menikah dengan WNI dapat memperoleh Kewarganegaraan RI dengan menyampaikanxxpernyataan menjadi warga negaraxdi hadapanxpejabat dengan syarat WNA tersebut sudah tinggal diiwilayah Republik Indonesia palingxsingkat 5 tahun berturut-turut atau paling singkat 10 tahun tidak berturut-turut.(Wirawan 2008)

Menjadi catatan, apabila persyaratan perkawinan campuran sesuai dengan Undang-Undang Perkawinan telah terpenuhi, maka pejabat yang berwenang tidak dapat menolak perkawinan tersebut. Dengan demikian, maka tindak pidana perkawinan semu secara hukum sulit untuk dibuktikan. Terkait dengan irisan hukum dalam pidana perkawinan semu ini, baik rumusan UndangUndang Perkawinan, maupun Undang-Undang Kewarganegaraan RI, memberi celah kepada masingmasing pihak untuk melakukan perkawinan semu (Syahrin 2017).

Dalam Hukum Pidana Keimigrasian, tindak pidana perkawinan semu diatur dalam Pasal 135 UU No 6 Tahun 2011 menggambarkan perkawinan semu sebagai perkawinan campuran untuk memperoleh dokumen keimigrasian dan/atau kewarganegaraan dari Negara Kesatuan Republik Indonesia.(Aji and Kurniawan 2018).

\section{Pemenuhan Unsur-unsur Pidana Perkawinan Semu}

Dalam praktiknya, tindak pidana perkawinan semu sulit untuk dibuktikan, karena dalam pembuktian suatu hukum pidana diperlukan sekurang-kurangnya dua alat bukti yang sah disebutkan sebagaimana dalam Kitab Undang-Undang Hukum Acara Pidana (KUHAP). Sistem pembuktian dalam hukum pidana diperlukan untuk membuktikan apakah tersangka bersalah atau tidak.

Dalam pidana perkawinan semu yang diatur dalam pasal 135 Undang-Undang Keimigrasian, terdapat beberapa unsur yang dapat menjadi pembuktian tindak pidana perkawinan semu. Adapun unsur-unsur tindak pidana perkawinan semu adalah sebagai berikut :

1. Setiap orang;

2. Yang melakukan perkawinan campuran, namun bukan merupakan perkawinan yang sesungguhnya;

3. Dengan maksud mendapatkan Dokumen Keimigrasian dan/atau untuk mendapatkan Kewarganegaraan Republik Indonesia;

4. Dipidana Penjara dan pidana denda.

Unsur-unsur yang disebutkan diatas, sulit dibuktikan dalam proses penindakan pidana perkawinan semu. Hal ini dikarenakan, unsur pembuktian perkawinan yang bukan perkawinan sesungguhnya, sulit dibuktikan karena apabila segala persyaratan yang diajukan oleh pihak-pihak yang melakukan perkawinan telah lengkap dan dinyatakan sah sesuai hukum yang berlaku maka perkawinan tidak dapat ditolak.(Aji and Kurniawan 2018)

Setelah perkawinan dicatatkan, maka orang asing yang melakukan perkawinan campuran ini dapat mengajukan pewarganegaraan. Hal inilah yang membuat banyak orang asing hendak melakukan perkawinan campuran, karena mereka tidak perlu melalui proses naturalisasi seperti biasa untuk mendapatkan kewarganegaraan Republik Indonesia.

\section{Penegakan Hukum Pidana Terhadap Perkawinan Semu}

Dalam praktiknya peraturan hukum keimigrasian harus lah di tegakan kepada seluruh elemen masyarakat baik itu WNI maupun WNA yang berada di Indonesia.Penegakan hukum Keimigrasian terhadap WNA meliputi :

1. Pemalsuan Identitas

2. Pendaftaraan orang asing dan pemberian dokumen orang asing

3. Penyalahgunaan izin tinggal

4. Kerawanan keimigrasian secara geografis dalam pelintasan

Didalam Bab XI UU No 6 Tahun 2011 Tentang tindak Pidana Keimigrasian mengatur tentang Ketentuan pidana yang dimana dari pasal 113-136 yang dimana 3 pasal tergolong overtreading yaitu pasal 133-135. Menurut penjelasan Undang-Undang Keimigrasian.UNDANG-UNDANG REPUBLIK INDONESIA, "Undang-Undang Republik Indonesia Nomor 6 Tahun 2011 Pasal 113-136," ACM International Conference Proceeding Series 18-April2, no. 1 (2016): 45-54. Tindak pidana perkawinan semu sendiri terdapat pada pasal 135 yang dimana dijelaskan bahwa orang yang melakukan perkawinan semu dengan maksud untuk mendapatkan Dokumen Keimigrasian dan/atau mendapaykan Kewarganegaraan Republik Indonesia dapat dipidana penjara paling lama 5 tahun dan denda paling banyak Rp.500.000.000 (lima ratus juta rupiah). Dijelaskan dalam pasal tersebut bahwa perkawinan semu adalah perkawinan campuran yang dilakukan untuk mendapatkan Dokumen Keimigrasian dan/atau Kewarganegaraan Republik Indonesia.(INDONESIA 2016).

\section{SIMPULAN}

Dalam urusan kegiatan orang asing masuk dan keluar wilayah Indonesia, Imigrasi mengemban tugas besar dalam menjaga tegaknya kedaulatan Negara. Imigrasi sebagai penegak hukum utama Keimigrasian, harus teliti dan tegas dalam menindak segala pelanggaran yang ada, baik dalam bentuk Tindakan 
Administratif Keimigrasian maupun Tindak Pidana Keimigrasian.

Perkawinan semu merupakan salah satu tindak pidana yang dapat merugikan Bangsa Indonesia. Hal ini karena, orang asing yang melakukan perkawinan campuran dengan maksud dan tujuan untuk mendapatkan Dokumen Keimigrasian dan/atau Kewarganegaraan Republik Indonesia tanpa melalui proses naturalisasi biasa.

Tindak pidana perkawinan semu hingga saat ini masih sulit untuk dibuktikan unsur-unsur pidananya, sehingga sulit untuk membuktikan bahwa orang asing tersebut melakukan perkawinan campuran dengan dalih untuk mendapatkan Dokim dan/atau Kewarganegaraan RI melakukan pelanggaran keimigrasian sehingga dapat dikenakan Tindak Pidana Keimigrasian.

Terkait adanya Pasal 135 Undang-Undang Keimigrasian, maka saran penulis yaitu dilakukan kajian ulang pada unsur-unsur pidana perkawinan semu sehingga pidana ini dapat dibuktikan secara konkret. Kemudian, Direktorat Jenderal Imigrasi dapat melakukan kajian bersama dengan instansi-instansi terkait dalam perumusan Undang-Undang maupun peraturan-peraturan lain, terkait tindak pidana perkawinan semu.

Penulis juga bersaran agar Pejabat Imigrasi yang berwenang dalam mengeluarkan Dokumen Keimigrasian, lebih berhati-hati dalam mengeluarkan Dokumen Keimigrasian. Perlu adanya peninjauan ulang untuk memastikan bahwa setiap orang asing yang mengajukan Dokumen Keimigrasian, tidak mempunyai maksud tertentu yang dapat merugikan Negara Republik Indonesia.

\section{DAFTAR PUSTAKA}

Aji, Koesmoyo Ponco, and Aditya Tri Kurniawan. 2018. "MENAKAR EKSISTENSI PASAL 135 UNDANG - UNDANG KEIMIGRASIAN TERKAIT PEMBUKTIAN PERKAWINAN SEMU PADA PIDANA KEIMIGRASIAN." Jurnal Ilmiah Kajian Keimigrasian 1.

Erna ratnaningsih (2018, 09 July). "Perkawinan Campuran Antara WNI dan WNA di Indonesia". Diakses pada 30 September 2021, dari https://businesslaw.binus.ac.id/2018/07/09/perkawi nan-campuran-antara-wni-dan-wna-di-indonesia/

INDONESIA, UNDANG-UNDANG REPUBLIK. 2016. "Undang-Undang Republik Indonesia Nomor 6 Tahun 2011." ACM International Conference Proceeding Series 18-April-2, no. 1: 45-54.

Syahrin, Muhammad Alvi. 2017. "Perkawinan Semu: Anomali Sosial Dan Implikasi Hukum." 2017.

Wirawan, Aditya. 2008. "Kajian Yuridis Perkawinan Semu Sebagai Upaya Untuk Memperoleh Kewarganegaraan Indonesia." 